\title{
Wspomnienie o profesorze Antonim Gabryelewiczu
}

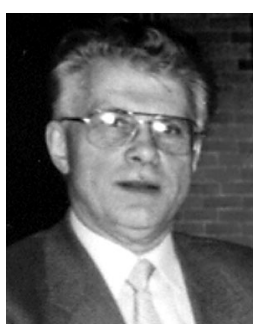

24 września 2010 r. zmarł nagle profesor dr hab. Antoni Gabryelewicz, wielki naukowiec, dydaktyk, klinicysta, a przede wszystkim nauczyciel i przyjaciel wielu polskich lekarzy.

Bardzo trudno pisze się o kimś, kto był tak ważny w życiu, w czasie przeszłym - był, pracował, odszedł... Nie będzie już przewodniczył żadnej sesji, nie wygłosi już żadnego wykładu, nie zadzwoni z radą: „Grażyna, za dużo ostatnio pracujesz". Bardzo trudno jest już tylko wspominać...

Profesor Antoni Gabryelewicz urodził się 16 lipca 1928 r. na ziemi białostockiej. Akademię Medyczną w Łodzi ukończył w roku 1952 i od tego czasu pracował w Klinice Chorób Wewnętrznych Akademii Medycznej w Białymstoku, zdobywając kolejno stopień doktora nauk medycznych i doktora habilitowanego nauk medycznych. Tytuł profesora uzyskał w roku 1976. W 1970 r. został kierownikiem Kliniki Gastroenterologii na tej samej uczelni.

Pana profesora Gabryelewicza pamiętam z czasów moich studiów w Alma Mater Bialostocensis jako dziekana, przed którym czuliśmy wielki respekt i trochę się go wówczas baliśmy. Ale prawdziwa znajomość rozpoczęła się w roku 1982, kiedy podjęłam pracę w Klinice prowadzonej przez Profesora. Była ona nie tylko miejscem pracy, była naszym drugim domem, Profesor potrafił wzbudzić w nas pasję i miłość do nauki, głównie do pankreatologii. Potrafit sprawić, że praca była jednocześnie naszym hobby. Dzięki niemu zdobywaliśmy kolejne stopnie i tytuły i stawaliśmy się rozpoznawalni w Polsce i poza nią jako Jego wychowankowie.

Profesor Gabryelewicz był wspaniałym naukowcem i dydaktykiem. Jego zainteresowania pankreatologią kliniczną i doświadczalną sprawiły, że zarówno on sam, jak i Klinika, którą kierował, zdobyła uznanie nie tylko w Polsce, ale także na świecie. Pan Profesor zorganizował Klinikę na poziomie europejskim, wprowadził nowoczesne techniki endoskopowe, umiał zgromadzić wokół siebie grono ambitnych ludzi, którzy pod jego kierunkiem bardzo szybko się rozwijali. Był promotorem 23 prac doktorskich i opiekunem 9 habilitacji. Większość jego „habilitowanych” wychowanków uzyskała tytuł profesora. Był jednocześnie naszym kierownikiem, mistrzem i przyjacielem.

Profesor Antoni Gabryelewicz był autorem i współautorem ponad 270 publikacji zarówno w pismach krajowych, jak i zagranicznych, autorem i redaktorem kilku podręczników gastroenterologii. Był członkiem zespołów redakcyjnych wielu czasopism - polskich i zagranicznych, pełnił odpowiedzialne funkcje w macierzystej uczelni i w Polskim Towarzystwie Gastroenterologii, którego prezesem był w latach 1985-1991. Był członkiem Zarządu Głównego International Association of Pancreatology, od lat przewodniczył Komisji Gastroenterologii i Hepatologii PAN, stwarzając dla nas członków tejże komisji - wspaniałą, przyjacielską platformę dyskusyjną.

Z jego inicjatywy powstała Robocza Grupa Trzustkowa Polskiego Towarzystwa Gastroenterologii, w której pracy brali udział wybitni pankreatolodzy krajowi i zagraniczni.

Profesor Gabryelewicz był członkiem honorowym: Polskiego Towarzystwa Gastroenterologii, Słowackiego Towarzystwa Medycznego oraz członkiem korespondentem Niemieckiego Towarzystwa Gastroenterologii. Przez dwie kadencje był członkiem Centralnej Komisji ds. Stopni i Tytułów oraz Zespołu Nauk Medycznych Komitetu Badań Naukowych.

Był doktorem honoris causa uczelni medycznej białostockiej, a także wrocławskiej i łódzkiej. W uznaniu zasług naukowych i dydaktycznych Profesor otrzymał wiele odznaczeń państwowych, a w tym roku, 5 listopada, miał otrzymać medal Gloria Medicinae. Byłam zaproszona na tę wyjątkową uroczystość...

Tak wielu rzeczy nie możemy zdążyć w życiu zrobić, wciąż nadrabiamy zaległości, doganiamy nasze marzenia i nie wiemy, kiedy będzie czas na podsumowanie. Profesor Antoni Gabryelewicz zdążył zrobić bardzo wiele, bardzo wiele nie dla siebie, ale dla nas - jego wychowanków. Był dla nas wzorem, mistrzem, przyjacielem, czasem krytycznym, ale zawsze pomocnym. Pogodny, serdeczny, z dumą obserwował nasz rozwój, cieszyły go nasze małe i duże sukcesy. Był nie tylko wspaniałym naukowcem, był wspaniałym człowiekiem, którego opłakiwaliśmy podczas uroczystości pogrzebowych.

Żegnaj, Profesorze. Żegnaj, Antoni. Będzie nam Ciebie bardzo brakowało. prof. dr hab. Grażyna Rydzewska 